\title{
Sciendo
}

\section{The Emergence and Restoration of the State: Latvia in 1918 and 1990}

\section{Andrejs Gusachenko}

Institute of Latvian History

University of Latvia

4 Kalpaka blvd.

Rīga LV-1050, Latvia

Email: andrejs.gusacenko@lu.Iv

\section{Vineta Kleinberga}

Latvian Institute of International Affairs

21 Pils str.

Rīga LV-1050, Latvia

Email: vineta.kleinberga@liia.Iv

Faculty of European Studies

Rīga Stradinš University

16 Dzirciema str.

Rīga LV-1007, Latvia

Email: vineta.kleinberga@rsu.Iv

\begin{abstract}
On 18 November 1918, the independent Republic of Latvia was declared in an extremely complicated international and domestic environment-the First World War was still going on, empires were collapsing, and ethnically and ideologically diverse military troops were fighting within the boundaries of Latvian territory. Despite the historical context of a previously tense relationship between Latvians and other ethnic groups, representatives of all minorities fought next to Latvians against the enemies of the Latvian state. Up until 11 August 1920, when the Peace Treaty with the Soviet Russia was signed, the prospects of de jure recognition of the newly established state were blurred; yet, the defeat of the White forces in the Russian Civil War opened the long awaited "window of opportunity", as a result of which Latvia managed to achieve its international recognition on 26 January 1921. More than seventy years later, on 4 May 1990, when the Declaration of Independence was adopted by the Supreme Council of the Latvian Soviet Socialist Republic (SSR),
\end{abstract}


the international and domestic situation was no less complicated. Latvia was forcefully incorporated into the Soviet Union in 1940 and became part of it, yet the economic and political deterioration of the Soviet Union, the national awakening in the Baltic States and other Soviet republics alongside the fall of the Berlin Wall gave momentum for the regime to change. On 21 August 1991, after the barricades and bloody clashes with the Soviet Special Purpose Police Units (OMON) in Riga on January and the failed coup d'état in Moscow in August, Latvia's independence once again became a reality.

In the events of the 1990s, the memories of 1918 and Latvia's independence in the period between the two world wars were crucial. It is manifested by the fact that Latvian statehood in 1991 was not established anew but restored. Acknowledging the importance of history on contemporary identification and policymaking, this article aims to provide an insight into the history of 1917-1922 and its resonance in the contemporary situation. Using the methodology of literature analysis and historical process-tracing it will reveal the complicated process of the state's formation and recognition in the period of 1917-1922, paying particular attention to the role of the minorities and diplomatic efforts. It will also uncover the resonance of the events of 1918-1922 in the 1990s, when Latvia's independence from the Soviet Union was declared, focusing in particular on aspects defining the statehood of Latvia and its citizenship. In this part, it will be argued that the history of 1917-1922 was brought back when the statehood of Latvia was concerned, while overshadowed by fifty years of the Soviet occupation, when the citizenship issue was on the agenda. Indeed, not only ethnic Latvians but also minorities living in Latvia played a decisive role in the efforts of restoring Latvia's independence. However, as a result of the Citizenship Law, ${ }^{1}$ adopted in 1994, more than one-fourth of the population-in most cases, representatives of the Russian-speaking community-were denied citizenship. This practice contrasts the Act that had been adopted in the interwar period, when Latvian citizenship was granted to all ethnic groups who were living within the borders of the then agreed Latvian territory, notwithstanding their diverse ideological background. Given this fact, the article provides future research opportunities related to perceptions of history in contemporary policy-making.

In this article the reference to the original Citizenship Law (Pilsonības likums in Latvian), adopted on 11 August 1994, will be made without referring to the amendments of later years. 
Keywords: ethnic minorities in Latvia, international recognition of Latvia, Latvian War of Independence, restoration of Latvian independence

\section{The emergence of a new state: the formation and international recognition of Latvia}

At the time when the Republic of Latvia was declared, the political and military situation in the region was highly complicated. Since the beginning of 1918, the whole territory of Latvia had been occupied by the German army; thus, after the proclamation, the power of the Provisional Government was rather nominal, in fact it was not even supported by the majority of the population. At the same time, after the defeat of Germany, the Red Army of Soviet Russia invaded Latvia, starting the Latvian War of Independence-a series of military conflicts, partly as fragments of the Russian Civil War, lasting from the end of 1918 until the signing of the Peace Treaty with Soviet Russia on August 11, 1920. In parallel, the formation processes of the Latvian state took place under the direction of the Provisional Government and the predecessor of the Latvian parliament-the National Council of Latvia.

\subsection{Minority issues during the state formation in $1918-1921$}

Due to the multicultural composition of the Republic of Latvia, ethnic minorities carried a notable role in these processes. As soon as the Republic of Latvia was declared, the equality of all nations, regardless of their ethnic, religious and confessional peculiarities, was declared before the law. Except for the titular nation - the Latvians - the representatives of all other nations living in the Republic of Latvia were declared as minorities with civil rights equal to the titular nation (Dribins, 2002, p. 51).

\subsubsection{Statistics of the ethnic minorities in the Republic of Latvia}

The First World War and the following events drastically influenced the demographic situation in Latvia as the mobilization and evacuation resulted in a huge decrease in the population. Before the war, 2,552,000 people lived in the territory of the later Republic of Latvia; a few years later, according to the results of the first census, held in 1920, the total population 
decreased to $1,596,131$, where ethnic minorities formed more than $28 \%$. The statistics for the main minorities is the following: Russians-124,746; Jews-79,368; Belarusians-75,630; Germans-58,113; Polish-54,567; Lithuanians-25,588; and Estonians-8,701 (Skujenieks, 1925, pp. 10, 6573). Concerning the economic status of the minorities, it has been observed that Germans and Jews belonged to the wealthiest and best educated segment; in its turn, Russians and Belarusians formed the poorest part of the population with a low percentage of educated people. As to Russians, due to the events of the First World War, the minority lost a vast part of economically active and educated people, decreasing the number of Russians in Latvia on more than two occasions; thus, at the end of 1918, the largest part of the minority consisted of low-educated, poor peasants (Gavrilin, 2015, pp. 234-235). Compared to Belarusians, a certain percentage of Russian intelligentsia lived in Latvia; it rose in the coming years because of Russian emigration in the aftermath of the Civil War and due to the return of refugees (Gusachenko, 2019, p. 51). The number of other minorities (except Jews and Germans) decreased in the first half of the 1920s, due to emigration to their home countries (Skujenieks, 1925, pp. 10, 65-73).

\subsubsection{Perceptions of Latvia's statehood and attitudes towards the Republic of Latvia}

Despite the declared equality of the minorities, their attitudes towards Latvia's statehood varied. Due to the complicated international and domestic political situation in 1918, the state of Latvia and the Provisional Government did not grant the credit of confidence even in the perception of Latvians (Stranga, 2010). Concerning the minorities, the World War, its aftermath in conjunction with the Civil War in Russia, and the emergence of new states literary destroyed their perception of "the old order". During 1918-1920, the political, military and social situation changed faster than their ability to adapt their political consciousness, which manifested itself in the attitudes of the minorities towards the Latvian state. In the context of attitudes and political loyalty, the minorities could be tentatively divided into two categories-the minorities who possessed political power over the region and had ruled over it in former times; and the remaining minorities who did not have such an experience in the past. The first category includes Russians, Germans and partly Polish, while the second category consisted of Jews, Estonians, Belarusians, Lithuanians ${ }^{2}$ and others.

2 Historically, Lithuania was linked to the Polish-Lithuanian Commonwealth, which partly controlled Latvia in the 16th-18th century, but in general Latvian Lithuanians almost did not have imperial or chauvinistic trends or manifestations. 
As far as the Russian minority was concerned, besides the abovementioned changes in their economic activity and education, certain transformation took place in the political consciousness of Russian intelligentsia-from the titular and political nation of the Russian Empire before the First World War, Russians became a minority with equal rights to other minorities in the unstable and ephemeral Republic of Latvia in the autumn of 1918 (Apine \& Volkovs, 2007, pp. 34-35). In general, the political mood and preferences of Russians at the end of 1918 varied from supporting monarchism (often manifested in chauvinistic and hostile attitudes towards the state of Latvia) or liberalism, advocated by intelligentsia, to sympathies towards leftist ideologies and Bolshevism, mainly shared by peasants and workers (Gusachenko, 2019, p. 63). The political views and the attitude of Russians towards Latvian statehood directly depended on the military processes of the Russian Civil War, during which the White forces successfully carried out offensive operations until the middle of October of 1919. Thus, in the perceptions of Latvian Russians, the future of Latvia after the defeat of Bolsheviks was uncertain and was imagined as an autonomous or federative formation within democratic Russia. However, the defeat of the White forces in the Civil War proved a turning point in the political consciousness of the Russian minority, starting to slightly increase the loyalty towards the Republic of Latvia.

The attitudes of Baltic Germans towards Latvian statehood were, in some aspects, similar to the perceptions of Russians. Until the second part of the 19th century, they had administrative, legislative and economic autonomy in the Baltic governorates under the nominal jurisdiction of the imperial government. The collective memory of the minority persisted even after decades of reactionary politics of the government and sometimes manifested itself in a chauvinistic way, causing confrontation with Latvians, which culminated in the events of 1905-1906. During the German occupation, some segments of Baltic Germans expressed sympathies towards Germany, especially after the revolution in Russia. These factors had long-lasting consequences during the formation of the Latvian state and even in the first half of the 1920s. Thus, they perceived the emergence of the new state with doubts and even in a negative way, which was reflected in a political confrontation between the National Committee of Baltic Germans and the National Council (Spārīts \& Dribins, 2000, pp. 64-67). Other tensions arose after the coup d'état carried out by Germans on April 16, 1919, and during the Battles of Cēsis in June 1919. Nevertheless, the political strain reduced in the middle of the $1920 \mathrm{~s}$, although it never disappeared completely. 
The Polish were largely represented in Latgale (in the eastern part of Latvia) because of the historical context-in the 16th-18th centuries, Latgale was part of the Polish-Lithuanian Commonwealth. Despite the partition of the Commonwealth, the Catholic Church and the Polish nobility preserved their influence in the region even during the rule of the Russian Empire. The influence, which often reflected a chauvinistic attitude towards the local peasants, remained even after the proclamation of the Republic of Latvia and pre-determined a negative attitude of the local nobility towards the Latvian statehood, proposing the incorporation of Latgale into Poland as an optimal future scenario for the region. This attitude was not expressed by the majority of Latvian Polish; in general, it manifested itself in the behavior of the nobles (Jēkabsons, 1996, pp. 26-28).

Concerning the so-called "second group" of minorities, the political views of Latvian Jews (in the early phase of Latvian statehood) may be notionally divided into three groups: supporters of Baltic Germans, restorers of Russian monarchy (despite the reactionary attitude of the imperial government towards Jews) and the left-oriented Jews, who sympathized with the Bolsheviks (Jēkabsons, 2013, p. 24). In its turn, the closest neighborsLithuanians and Estonians-in general behaved loyally towards the Latvian state and supported the sovereignty of Latvia.

Despite the large number of Belarusians in Latvia, the minority almost did not possess its national identification, which partly could be explained by the drastically low percentage of educated Belarusians. For this reason, they did not manifest a notable position towards Latvian statehood, at least in the early phase. Belarusians were the only minority who did not have a national country abroad and never had the experience of national statehood. It even affected the national identification of educated Belarusians, whose sympathies were often on the side of the Union of Soviet Socialist Republics (USSR) and the Soviet Republic of Belarus. Other Belarusians usually defined themselves as Russians, Polish or Latvians and were often objects of political speculation (Jēkabsons, 2001, pp. 105-109, 111, 124-125).

In general, all the minorities had their right and left wings, with the latest ones dominating during the early period of the Latvian state from the end of 1918 till March 1919. Bolshevik sympathies strongly diminished during the regime of Stučka and its peculiarities (Gusačenko, 2019, pp. 85-86). The turning point in the political perceptions of Latvian statehood and the increase in confidence towards the Provisional Government took place after the defeat of the West Russian Volunteer Army led by Pavel Bermondt- 
Avalov on 11 November 1919. In the perceptions of Lithuanians and Estonians as well as a certain segment of Jews, it stabilized the position of Latvian statehood and clarified the vision of the future (Šilde, 1976, pp. 335-336). The Bermondt's affair matched the great offense of the White Russian armies in the Civil War towards Petrograd and Moscow, which did not achieve their goals and retreated in November, marking the outcome of the Civil War in favor of the Soviets. It crushed the expectations of the anti-Bolshevik segment of Russians (and partly the German and Jewish minority) of the resurrection of the Constitutional Assembly, where Latvia's future destiny would be defined. Thus, they realized the need to face reality and integrate themselves as a minority in the Republic of Latvia, whose stability was provided by the Peace Treaty with Soviet Russia in 1920 and de jure recognition of Latvia's state in 1921.

\subsubsection{The minorities in the Latvian War of Independence}

The truly complicated War of Independence became a test of stability for the Latvian government. The outcome of the War of Independence was an achievement of all people living in Latvia-all the minorities took part in it. However, due to the peculiarities of the largest minorities and their historical military experience, the minorities participated in the war to varying degree. Thus, Germans and Russians were the only minorities who participated in the Latvian War of Independence by creating certain military formations - the Landeswehr, the Voluntary Riflemen Squad of Liepāja (Prince Lieven's Squad), the Partisan Squad of the Colonel Mikhail Afanasyev and others. It has to be acknowledged that Afanasyev's squad was the first anti-Bolshevik military formation in Latvia which got involved in the clashes with the Red Army in late November 1918 (Gusačenko, 2019, pp. 67-68). In its turn, around $80 \%$ of the Landeswehr's volunteers were Baltic Germans and they played a key role in the liberation of Kurzeme and Riga (Dribins, 2007, pp. 153-154). Unfortunately, the military conflict between the Estonian army and Latvians on the one side and the German army with the Landeswehr on the other had long-lasting consequences. Nevertheless, after the battle of Cēsis, the Landeswehr forces successfully took part in the liberation of Latgale.

During the Bermondt's affair (8 October - 11 November 1919), a certain number of local Germans and Russians participated in the West Russian Volunteer Army ('Chto proishodit v Kurlandii', 1919, p. 4). A nominal presence of other minorities and even Latvians took place there as well (Ciganovs, 2013, p. 81). Yet, Russians and Baltic Germans did not participate only in 
the abovementioned formations; many were the soldiers of the Latvian army along with Jews, Belarusians, Lithuanians, Estonians and other minorities, who also played an important role during the War of Independence, and were later awarded the Order of Lāčplēsis.

\subsubsection{Investment of the minorities in the political formation of the state}

The minorities did not participate in the proclamation of the Republic of Latvia as members of the National Council, but were part of it (except Estonians and Belarusians) since December 1918 (Feigmane, 2000, pp. 22-23). Due to the political confrontations, Baltic Germans appeared on the political horizon of the Republic of Latvia only in July 1919, despite the fact that the Baltic Germans and Jews were the only minorities whose representatives were elected in the Provisional Government. Russians, Jews and Germans participated in the Constitutional Assembly (May 1, 1920 - November 7, 1922) and later-like the Polish-were elected in the Parliament of Latvia (Dribins, 2007, pp. 153-154; Bobe, 2006, p. 152). The Polish ${ }^{3}$ and Lithuanians were represented in the National Council, but were not able to enter the Constitutional Assembly. The participation of the minorities in the political processes was not cloudless-confrontations appeared between Russians, Germans and Latvians, concerning issues of agrarian reforms, language status and the directions of certain political parties. Nevertheless, despite their collective memory and other peculiarities, the minorities proved their ability to take part in the formation of a democratic state since the beginning and during all the parliamentary periods of the interwar Republic of Latvia.

\section{The process of recognition of the Republic of Latvia: important turning points}

At the end of 1918, as the Republic of Latvia was proclaimed and the War of Independence had started, another struggle for independence began-the struggle for the international de jure recognition of Latvia, which took place in the cabinets of high-level politicians in Paris, London and other cities of Western Europe (Lerhis, 2005, p. 66).

3 The Polish were not elected in the Constitutional Assembly but their interests were represented by a Latvian Member of the Parliament from the Polish-Latvian agrarian party. 


\subsection{Latvian delegation at the Paris Peace Conference}

The unexpectedly fast de facto recognition of Latvian independence by Great Britain, signed on 11 November 1918 (the so-called Balfour memorandum), even before the official proclamation of the Republic of Latvia, and by Germany on 25 November 1918, gave hope for a quick de jure recognition, expected during the Paris Peace Conference which opened on January 18, 1919 (Šilde, 2007, p. 47). In December 1918, the Latvian delegation, led by statesmen Jānis Čakste, Zigfrīds Anna Meierovics, Jānis Seskis and five other officials, was formed (Latvija Parīzes miera konferencē, 1919, p. 42). The delegation arrived at the Conference on 23 January 1919, five days after its opening. The primary tasks of the delegation were: (1) to secure the international de jure recognition of the Latvian state; (2) to support the Entente and other countries in the Latvian War of Independence; (3) agreement on loans for food and import of other supplements; and (4) evacuation of German military forces from Latvia (since summer 1919) (Seskis, 1938, p. 285)

\subsection{Latvian de jure issue in the perception of the superpowers at the Paris Peace Conference}

Despite the hopes, the de jure recognition issue took much longer than was expected. The Paris Peace Conference, with representatives of 32 countries participating, was led by three superpowers-France, Great Britain and the United States of America (USA), whose political and economic interests in Eastern Europe were directly connected to the anti-Bolshevik camp of Russian White forces and organizations of Russian political representatives. The issue of newly independent countries in the context of "united and indivisible" Russia was perceived in a negative way by Russian political representatives and, as a result, by their allies - the Entente and the USA. The superpowers supporting anti-Bolshevik Russia in the Civil War avoided de jure recognition of the new states, which emerged as a result of the collapse of the Russian Empire; they kept their biding position due to the unclear situation in the Russian Civil War. In the perceptions of Russian political representatives, the destiny of the new states had to be defined only by the Russian Constitutional Assembly after the defeat of the Bolsheviks. This view affected the position of the superpowers, and, as a result, the attitude of the Board of the Paris Peace Conference, and manifested itself in the 34 notes sent by the Latvian delegation during 1919 being ignored (Latvija Parīzes miera konferencē, 2017, pp. 43-47). 
In addition, de jure recognition was negatively affected by the unstable domestic situation in Latvia. The coup d'état organized by Germans in Latvia on 16 April 1919 was an additional argument questioning the stability of the Latvian government and provided an additional obstacle for de jure recognition of the state, led by an unstable government. The situation remained unclear even after Bermondt's defeat, which proved the stability of the Latvian government, but not in the perception of the superpowers at the Paris Peace Conference. In its turn to stabilize the military situation in Latvia, the government started peace negotiations with Soviet Russia, which elicited a negative reaction from the Entente and Russian political representatives in Paris (Šiliņšs, 2019).

By the end of 1919, the general international issues concerning "the new world order" were solved and the Paris Conference approached its final phase. The majority of the participants were leaving and, on 15 December 1919, the Latvian delegation left the Conference as well. Its mission was continued by the Latvian Diplomatic Mission in Paris (Bražūna, 2012, pp. 84-85). Despite the expectation of quick de jure recognition of the Latvian state, the delegation did not achieve its primary mission due to unexpectedly huge obstacles. Concerning the events of the Russian Civil War, which was the main obstacle in the context of de jure issue, the plans of the Russian White Army forces to capture Moscow and Petrograd failed, the troops withdrew and the situation confidently turned in favor of Bolsheviks, which increased the hopes of a sooner end to the Civil War and possibly a change in the attitudes towards the Latvian case.

\subsection{De jure issue in 1920}

In early 1920, the Diplomatic Mission put in additional efforts to achieve the former aim by trying to enter the League of Nations, which could aid de jure recognition. These efforts were unsuccessful mainly due to the position of France, who still supported the White movement in Russia. The same position was shared by the USA and Great Britain. Officially, the refusal was based on huge doubts about the stability of the Republic of Latvia, where the War of Independence was still going on, despite the signing of Armistice between Latvia and Soviet Russia on 30 January 1920. The League of Nations distrusted its defense abilities in the case of a full-range military conflict with Soviet Russia, which could have resulted in engaging the former in a potential conflict if Latvia entered the League of Nations (Latvijas vēstnesis, 1998, p. 1). 
Despite the refusal of de jure changes, which occurred in de facto status recognition, on 20 April 1920 it was recognized by France and a few other countries. At the same time, starting from 14 April 1920, peace negotiations between Latvia and the Soviet Russia took place, which resulted in the signing of the Peace Treaty on 11 August 1920. Paradoxically, Soviet Russia became the first state to de jure recognize the Republic of Latvia. The Peace Treaty had another advantage as well-the threat of a military invasion in Latvia was removed but it still did not guarantee membership in the League of Nations (Šilde, 2007, p. 52).

\subsection{The turning point in the position of superpowers}

The turning point in the process of de jure recognition came in autumn 1920, after the retreat and evacuation of the Russian army, commanded by Pyotr Wrangel, from Crimea. The Russian Civil War was not over and lasted until the end of 1922 but its main phase was passed in favor of Soviet Russia. The White movement lost the support of superpowers (namely, France) and the future of Russia was determined as a Soviet state. Thus the de jure refusal of new states lost its topicality. In fact, another issue became topical concerning the so-called cordon sanitaire - the chain of new states serving as a military barrier between Western Europe and Soviet Russia (Počs, 1971, pp. 121-122).

In December 1920, Foreign Minister of Latvia Z. A. Meierovics visited President of France Philippe Berthelot, British Foreign Secretary George Nathaniel Curzon, Prime Minister of Italy Giovanni Giolitti and other political leaders to clarify the attitudes towards the Latvian issue. The results ranged from refusal to full support. These meetings and the international political context inspired new hopes for a quick recognition.

On 26 January 1921, at 5 p.m., the Supreme Council of Allied Powers unanimously decided to recognize de jure the status of the Republic of Latvia, which was signed by the representatives of France, Great Britain, Italy, Japan and Belgium. The recognition by other countries (42 countries in total) soon followed (Sarkanis, 1999, p. 37). De jure recognition became the "entrance pass" to the League of Nations—on 22 September 1921, Latvia became a fully legitimate member of the international organization.

Despite these achievements, the de jure issue had not been solved completely - the status was not recognized by the USA. In general, such a position was directly related to US interests in the Far East in Russia, where 
the Far Eastern Republic was founded in 1920. In fact, it was a nominally independent buffer state that was established in the aftermath of the Russian Civil War between the territories occupied by Japan and Soviet Russia (Wood, 1997, pp. 715-718). To avoid the strengthening of Japan, whose forces partly controlled the Far Eastern Republic, some US congressmen were close to recognize its independence and even de jure status; yet, in such a case, the USA would have had to recognize de jure status of Latvia and other countries against the position of other congressmen who supported the previous political course of US foreign diplomacy. In the second half of 1922, Japan moved its forces out of Russia and all of Far East was soon occupied by Soviet Russia, who automatically removed the last obstacle on the way towards de jure recognition by the USA of the new countries that emerged in Europe (Jēkabsons, 2018, pp. 23-24). As a result, on 28 July 1922, the United States recognized de jure the status of Latvian state.

After three and a half years of hard efforts of Latvian diplomacy during highly complicated domestic and international political and military situation, the Republic of Latvia became the subject of international law with a permanent and irrevocable status as a stable base of democratic state (Ministry of Foreign Affairs of the Republic of Latvia, 2019). Because of activities of the Latvian delegation and the Diplomatic Mission during the de jure recognition process, the fundamental basis of Latvian diplomacy was founded and new relationships were established, representing the state of Latvia in the world of international diplomatic society.

\section{Restoration of the state: regaining of Latvia's independence}

\subsection{The conceptual frame of Latvia's independence in the 1990s}

The abovementioned "irrevocable status" was illegally and forcefully interrupted by the secret protocol of the Molotov-Ribbentrop Pact and incorporation of Latvia in the USSR as a result of the Second World War. The occupation lasted for almost fifty years and dramatically changed the economic, ethnic and cultural landscape of Latvia by implementing forced industrialization and collectivization, deportations, immigration and Russification, as well as deploying the Soviet military bases throughout the Latvian territory. Protests against environmental and cultural degradation in the mid-1980s preceded the formation of a broad anti-Communist 
movement, resulting in the establishment of the first openly anti-Communist civil rights organization in the USSR - the Helsinki-86-in 1986, and a political change requesting political organizations such as the Latvian National Independence Movement (Latvijas Nacionālā Neatkarības kustība, LNNK) and the Popular Front of Latvia (Latvijas Tautas fronte, LTF), both in 1988. However, claims for Latvia's independence were not initially on the agenda of these organizations; instead, it was democratization, civil rights and a greater autonomy of the Socialist republics that was requested (Jundzis, 2013, p. 4). Even later, when the idea of independence came on the agenda, the opinions diverged on how the independence should be framed: as a restoration of the 1918 republic, emphasizing the continuity of the state and renewing its 1922 Constitution, or as an establishment of a democratic and independent state on the premises of the Soviet republic, yet recognizing the fact of the occupation (Jundzis, 2013, pp. 7-9). While the LNNK followed the course of "restoration", the LTF was not so explicit. It is revealed that, in 1989, the LNNK together with other right-wing oriented civic organizations (e.g., Helsinki-86, Environmental Protection Club) declared its programmatic aim of "restoring" the democratic state of Latvia on the basis of its 1922 Constitution, while the position of the LTF was more moderate, adopting the goal of an independent Latvian state that would follow and develop the traditions of a democratic and parliamentary Republic of Latvia, yet would accommodate the legacies of the Soviet regime. In a way, the LTF as a mass movement tried to balance the diverse ideological preferences of its followers, ranging from reform communists to radical nationalists. It is maintained that up until the very elections of the Supreme Council of the Latvian SSR on 18 March 1990, it was not clear what kind of statehood the LTF would support (Jundzis, 2013, p. 12). However, the idea of independence had already found a solid basis in the society-in 1990 , the total of $85 \%$ of Latvians and $26 \%$ of other ethnic groups supported the idea of an independent state (Bleiere et al., 2005, p. 393), which allowed the LTF to gain considerable support in the elections. It got 131 seats out of 201 in the Supreme Council of the Latvian SSR (Krūmiňš, 2018, p. 135), which equipped the LTF with enough legitimacy to intensify work on the independence declaration of Latvia.

A few weeks later, on 4 May 1990, the Supreme Council of the Latvian SSR adopted the declaration 'On the Restoration of Independence of the Republic of Latvia', ${ }^{4}$ with 138 deputies voting for it (134 was the required majority), one abstaining, and the others not participating in the vote (Krūminsš, 2018,

4 Author's translation from Par Latvijas Republikas neatkarības atjaunošanu (in Latvian). 
p. 135). The declaration mentions explicitly the goal to restore Latvia's independence based on the 1922 Constitution, emphasizing the legal continuity of the state of Latvia established in 1918. The declaration underlines the illegal nature of the occupation of Latvia in 1940, thus acknowledging the validity of its de jure status in international affairs, i.e. "the Republic of Latvia still exists de jure as a subject of international law, recognized by more than 50 countries in the world" ${ }^{5}$ (Par Latvijas Republikas neatkarības atjaunošanu, 1990). With this, the LTF-now in power-positioned itself as a supporter of the "restoration" of the 1918 state, and efforts to implement the independence of Latvia, again named the Republic of Latvia, began to take turns. These efforts did not go unnoticed. It is mentioned that after the declaration of independence "a peculiar period of double-government" began: on the one hand, the Supreme Council of the Republic of Latvia worked on independence-related legislation, reorganized state institutions, initiated economic reforms towards market economy and began to establish customs offices on borders; on the other hand, the USSR authorities, the Communist Party, the Soviet army, border guard and the Committee for State Security were still present (Klišāns, 2018, p. 380). President of the USSR Mikhail Gorbachev issued decrees to repeal the declaration of independence; proSoviet forces combined their efforts against independence in the so-called All-Latvia Rescue Committee; an attack on the building of the Supreme Council was organized by the pro-communist International Front of the Working People of the Latvian SSR (Interfront), fighting for Latvia's stay in the USSR with the support of the military (Bleiere et al., 2005, p. 397). A massive disinformation campaign was launched in the media warning people against the restoration of so-called "fascist nationalist dictatorship" (Klišāns, 2018, p. 383). The pro-Soviet efforts to stop Latvia's independence culminated on 20 January 1991, when the OMON forces attacked the Ministry of Interior. Five people were killed there, and during the period of the barricades and the coup d'état in Moscow three more were killed and many wounded (Krūmiņš, 2018, pp. 136-137).

\subsection{Independence in 1991 and international recognition}

A "window of opportunity" for the Baltic States opened in August 1991, when the coup d'état against Gorbachev in Moscow by the Communist hardliners and the military took place. In Riga, the buildings of television, radio and international telephone bureau were occupied by the Soviet army and the OMON forces. On August 21, when the OMON forces were

5 Authors' translation from Latvijas Republika joprojām de jure pastāv kā starptautisko tiesību subjekts, ko atzīst vairāk nekā 50 pasaules valstis (in Latvian). 
approaching the Supreme Council, attacking the barricades that protected the building, the Supreme Council made a fast and decisive decision to adopt the Constitutional Law on the statehood of the Republic of Latvia (Bleiere et al., 2005, p. 410). This law declared the restoration of the Republic of Latvia de facto, removing the transition period, which was introduced by the Declaration of Independence in order to ensure transition from a socialist state to a democratic one via a legal and negotiations-based approach. The law states that from then on "Latvia is an independent, democratic republic wherein the sovereign power of the State of Latvia belongs to the people of Latvia and the statehood thereof is determined by the 15 February 1922 Constitution of the Republic of Latvia" (Law on the Statehood of the Republic of Latvia, 1991). With this, the Republic of 1918 was de facto restored, finalizing the debate about the conceptual choice of Latvia's path to independence.

The failed coup d'état in Moscow with the consequent collapse of the Soviet Union allowed to continue with the non-violent transition to Latvia's renewed status. Lithuania and Estonia recognized the independence of Latvia on August 22. Iceland followed on August 23, being the first Western country to recognize Latvia's independence. On August 24, Latvia's independence was also recognized by Boris Yeltsin, President of the Russian Federation, paving the way to recognition by many other world countries (79 up to 18 September 1991, including the USA on 2 September and the USSR on 6 September) (Bleiere et al., 2005, p. 410). Indeed, the opinion of the Western countries who had been hesitant to support the Baltic independence efforts at the end of the 1980s, due to high hopes with regard to Gorbachev's perestroika, changed when the attempts to initiate reforms in the political governance of the USSR failed, the democratic forces in the republics of the USSR, including Russia, raised their voices, and after the coup d'état in Moscow the prospects for keeping the USSR together faded. In many cases the Western countries-such as the USA-had not recognized the incorporation of Latvia in the USSR and the establishment of the Latvian SSR, thus with the recognition they just reaffirmed their support to the country that was established in 1918. In several cases, countries such as Sweden ${ }^{6}$ recognized Latvia as a newly established state. It has been acknowledged that the

$6 \quad$ However, the Swedish diplomat Lars Peter Freden writes in his memoirs that the Swedish government recognized the independence of Latvia (as well as of Estonia and Lithuania) on August 27, 1991, and decided to renew diplomatic relations with these countries. However, when the agreement about the establishment of the diplomatic relations was being signed the next day, the word "establishment" had been changed to the "restoration" of diplomatic relations (see Fredēns, 2007, p. 194). 
form that the countries chose to recognize Latvia's independence and renew diplomatic relations was determined by the attitude of particular countries towards the incorporation of Latvia (and other Baltic States) in the USSR (Bleiere et al., 2005, p. 411).

\subsection{The citizenship issue in 1990}

The restoration of Latvia's independence on the basis of the 1922 Constitution ensured the legal continuity of the state, allowing it to profit from the legal status as a de jure existing country in international affairs. By that, the fact of the illegal occupation in 1940 became a reference point through which the activities carried out by the Soviet government in the territory of Latvia were measured and further policies initiated. It impacted the attitudes towards such issues as the withdrawal of Soviet troops, dealing with the consequences of immigration, as well as language policy and denationalization of Latvian property. Moreover, such an approach provided a historical narrative both to the political elite and the civil society that Latvia had its past in the democratic and independent republic. For identity formation and national self-confidence, the importance of perceptions of the "noble" roots should not be underestimated. It could be argued that the collective memory of being part of the Western world was decisive on Latvia's path towards the membership in the Euro-Atlantic structures. Indeed, Latvia's accession to the European Union is often referred to as "returning" to Europe.

However, the restoration of the 1918's republic brought along an issue of Latvian citizenship, which, although it has lost much of its intensity after the successful integration in the Euro-Atlantic structures, still continues to cause controversies in contemporary Latvia. Namely, by the decision of the Supreme Council of the Republic of Latvia 'On restoration of the citizenship rights of the Republic of Latvia and basic rules for naturalization'7 on 15 October 1991, which was adopted with an aim to determine a set of citizens, who were eligible to participate in the parliamentary elections of independent Latvia in 1993, and the succeeding Citizenship Law of 11 August 1994, the citizenship of Latvia was granted only to the persons who had been Latvian citizens up to 17 June 1940, and their descendants. Such a decision left approximately 750,000 Latvian inhabitants with the status of non-citizens (Naturalization Board of the Republic of Latvia, 2009, p. 11), restricting certain political and economic rights, for example, to stand in and

7 Author's translation from Par Latvijas Republikas pilsoṇu tiesību atjaunošanu un naturalizācijas pamatnoteikumiem (in Latvian). 
vote in elections or buy property. With the population of 2.54 million at the beginning of 1994 (Central Statistical Bureau of Latvia, 1994), more than one-fourth of the population was thus left out of the so-called demos of the state of Latvia.

The citizenship issue could be arguably the most important factor that determined the choice towards restoring not establishing the state. Latvia's ethnic composition had changed dramatically during the Soviet times, when mass immigration from all over the Soviet Union but mainly from Russia, Belarus and Ukraine was intentionally forced. The immigration rate from 1940 to 1990 was 941,000 people altogether, and as a result of the immigration, Latvians constituted just $52 \%$ of the population in 1989 (compared to the almost $80 \%$ before the Second World War) (Bleiere et al., 2005, pp. 378379). Of the population of 2.67 million in 1989 (Central Statistical Bureau of Latvia, 1989), 1.39 million were Latvians, while more than a million were so-called Eastern Slavs (Russians-905,500; Belarusians-119,700; Ukrainians-92,100), forming $42 \%$ of the population (Zvidriņšs, 2018, p. 504). As regards other ethnic groups, their number had not changed dramatically by 1989 in comparison to the situation in 1918, except for Germans and Jews, whose numbers had diminished substantially, especially those of the former. The figures reported for 1989 were the following: Polish-60,500, Lithuanians-34,600, Jews-22,900, Roma-7,000, Germans-3,800, and Estonians-3,300 (Zvidriňš, 2018, p. 504).

Thus, in the 1990s, the most important difference with the period of 19171922 was the high proportion of the Russian-speaking population in Latvia. Compared to the situation in 1918, at the time when the Republic of Latvia was declared, the number of Russians had increased by more than seven times. Such an increase in the Russian-speaking part of the population, alongside the overall Russification policy, left the Latvians the perception that their existence was endangered, which led to favoring the exclusive approach regarding the citizenship. This perception was probably even more strengthened by the realization of the actual number of the citizens of 1940 and their descendants in Latvia in 1989, which became evident after the Citizens' Movement (established in 1989 by the then active political and civil organizations, such as the LNNK, Helsinki-86, the radical wing of the LTF, etc.) called them to register. The main aim of this activity was to identify the number of citizens and potential candidates in advance of the next steps towards independence; yet, after the appeals of the Citizens Movement's more radical wing, it was accepted by the LTF that the Citizens' Congress, elected by the registered citizens, could form a "reserve" government, which would follow the 
course of independent Latvia without cooperating and compromising with the Communists, in case the attempts to do it in the so-called parliamentary way via the Supreme Council of the Latvian SSR failed. It has been revealed that before the elections of the Citizens' Congress (in April 1990), 806,974 people registered as citizens of 1940 and their descendants (Jundzis, 2013, p. 9). Although this fact exemplifies the support of a huge part of the population to the ideas of independence in highly uncertain political circumstances-before the elections of the Supreme Council of the Latvian SSR and the adoption of the Independence declaration-it also indicates the minority status of the citizens of 1940 and their descendants in 1990 in Latvia, which could have inspired thoughts on the need to legally strengthen the status of pre-1940 citizens and their descendants.

However, the decisions on citizenship disillusioned many supporters of an independent Latvia who were left without the citizenship in the 1990s. It can be assumed that many of them were supporting the move towards the independence of Latvia and stood on the barricades throughout 1991. A few facts may be given to illustrate the situation. On 17 March 1991, the Unionwide referendum on the preservation of the USSR took place. Governments of the Baltic States refused to take part in it and organized alternative referendums about their independence instead. In Latvia, the referendum took place on 3 March 1991, and 87.5\% of the voting population (1.9 million people) participated in it; of them $73.8 \%$ voted for independence (Bleiere et al., 2005, p. 409). In figures, around 1.2 million people, or $65 \%$ of the voting population, voted for it, which indicates that not only ethnic Latvians or pre-1940 citizens and their descendants but also representatives of other ethnic groups or immigrant communities voted for the independence. The number of opponents to independence was considerably lower- $24.7 \%$ of the voting population or 411,500 people voted against Latvian independence, constituting $22 \%$ of the voting population. These numbers largely coincide with the results of the USSR referendum on 17 March 1991, which, though boycotted by the government of the Republic of Latvia, was held in Latvia with the support of the Communist Party and the military. One-fourth of the voting population-501,300 people took part in it, and $95 \%$ voted for the preservation of the USSR. In figures, it is 484,800 people, constituting around $25 \%$ of the voting population. It should be noted that a huge part of the voters were officers of the Soviet military, the majority of who left Latvia as a result of the withdrawal of the troops in 1994. It was estimated that the number of people who formed the Soviet military troops in Latvia in the transition period of 1990-1991 was around 60,000 (Jundzis, 2014, p. 4). 
Although the issue of support to Latvian independence in interaction with the citizenship issue is much more complicated than the abovementioned facts, two conclusions can be drawn. On the one hand, more than half of the people living in Latvia in 1991 supported the independence of Latvia. On the other hand, the proportion-one-fourth of the voting populationbeing against it was a factor serious enough to consider, especially in the volatile political circumstances at that time and in a situation where ethnic Latvians formed only half of the population of Latvia. So the decision of the government can be understandable and illustrates how self-confidence, regained by a reference to the 1918 history, can be overridden by fear, imposed on the nation by the post-1940 events.

\section{Conclusion}

Independent Latvia emerged and re-emerged under highly uncertain and volatile circumstances. The self-sacrificing activities of Latvian statesmen led to the recognition of the Republic of Latvia by the world's superpowers; with this the basis for international relations was established, which was further extended and developed during the interwar period. International recognition was a highly important factor marking the irreversible character of independence, which notwithstanding the violation of it by the Soviet Union proved to be true in the long-term perspective.

The issue of people who belonged to the set of the citizens of the independent state turned out to be more complicated. Due to the historical peculiarities, the relationship between Latvians and some ethnic minorities was rather tense at the moment when the state of Latvia was formed. The trend can be observed in the context of Baltic Germans, the Polish (its nobility) and the community of conservative Russians, and can be explained by the heritage of the collective memory of the minorities that more or less prevailed, for centuries, in the political, administrative, economic and educational realms of the region. Despite it all, the minorities took part in the Latvian War of Independence on the side of anti-Bolshevist forces since the early days of the Republic of Latvia and later in the Latvian army. After the Latvian War of Independence, the minorities successfully participated in the social, cultural and political processes of the state, especially during its parliamentary period until 15 May 1934. 
While in 1918 Latvia chose an inclusive approach towards citizenship, including in it all ethnic groups living within the boundaries of the Latvian territory, in the 1990s an exclusive approach was chosen, recognizing only the citizens of the pre-1940 state and their descendants as citizens. In this, the role of historical memory is undeniable, establishing a narrative of a noble but oppressed state. Indeed, on the one hand, the courage of the Latvian nation to do the brave proclamation act of 1918 fed the national awakening movement at the end of the 1980s, leading to the restoration of the "noble" 1918 republic. On the other hand, repressions of the Soviet regime towards the Latvian nation as well as forced immigration and Russification overshadowed the positive post-First World War experience of ethnic co-existence, which allowed the fear of returning to the status of an "oppressed" state to dominate in the reasoning. Thus, legalization of the fact of the Soviet occupation was the primary concern in the 1990s, and for this purpose the 1922 Constitution proved to be an appropriate tool.

Overall, this article revealed only a few aspects of the very complex history of founding and consolidation of the state a hundred years ago, and its resonance in contemporary history. November 18 and May 4 are two national holidays, celebrating the establishment and the restoration of independent Latvia, respectively, and aiming to consolidate the nation around the narrative of a brave, tough and suffering nation. Post-Second World War history has contributed to the emphasis on the "suffering" part of it; yet, history altogether contains countless examples of courage and co-existence that should be further explored to foster a more positive and cooperative narrative across all parts of the society.

Andrejs Gusachenko is a scientific assistant at the Institute of Latvian History and a doctoral student at the University of Latvia. His scientific interests are focused on the Russian anti-Bolshevik movement in the Republic of Latvia in 1920-1940, Latvian War of Independence, Russian emigration and minority in the same period. The author has published scientific articles concerning the topics in academic as well as popular scientific journals.

Vineta Kleinberga is a researcher at the Latvian Institute of International Affairs and Faculty of European Studies at Rīga Stradinš University. Her research interests focus on the dynamics of the EU-bound integration and Latvia's membership in the EU, as well as the formation, projection and perception of narratives domestically and in international affairs. She holds a master's degree in political science and has ten years of experience in the government sector. 


\section{References}

Apine, I. \& Volkovs, V. (2007), Latvijas krievu identitāte [Latvian Russian identity], Rīga: LU, FSI, pp. 34-35.

Bleiere, D.; Butulis, I.; Feldmanis, I.; Stranga, A. \& Zunda, A. (2005), Latvijas vêsture: 20. gadsimts [History of Latvia: 20th century], 2nd ed., Rīga: Jumava.

Bobe, M. (2006), Ebreji Latvijā [Jews in Latvia], Rīga: Šamir.

Bražūna, A. (2012), Francijas loma Latvijas ārpolitikā (1921.-1933. g.) [The role of France in Latvia's foreign policy], $\mathrm{PhD}$ thesis, Rīga: Latvijas Universitāte.

'Chto proishodit v Kurlandii' (1919), [What's happening in Courland], Segodnya, 15.10.1919.

Central Statistical Bureau of Latvia (1989), ISG010. Population, population change, and key vital statistics, Database. Retrieved from http://data1.csb.gov.lv/pxweb/ en/iedz/iedz_iedzskaits_ikgad/ISG010.px/ [accessed 18 Sep 2019]

Central Statistical Bureau of Latvia (1994), ISG010. Population, population change, and key vital statistics, Database. Retrieved from http://data1.csb.gov.lv/pxweb/ en/iedz/iedz_iedzskaits_ikgad/ISG010.px/ [accessed 18 Sep 2019]

Ciganovs, J. (2013), Latvijas armijas intendantūras dienesti (1919.-1940.) [Latvian Army Intendant Services, 1919-1940], Rīga: LU.

Dribins, L. (2002), Ebreji Latvijā [Jews in Latvia], Rīga: Elpa.

Dribins, L. (2007), 'Vācieši Latvijā' [Germans in Latvia], in L. Dribins (ed.) Mazākumtautības Latvijā [Minorities in Latvia], Rīga: LU, FSI, pp. 153-154.

Feigmane, T. (2000), Russkie $v$ dovoennoi Latvii. Na puti k integracii, Rīga, BKI.

Fredēns, L. P. (2007), Baltijas brīvības cel̦š un Zviedrijas diplomātija 1989-1991 [The Baltic way to freedom and Swedish diplomacy 1989-1991], Rīga: Atēna.

Gavrilin, A. (2015), 'Russkie emigranty v mezhvoennoi Latvii: Pravovoi status i popytki samoorganizatsii,' in Rossiia i Latviia $v$ potoke istorii. 2-ia polovina XIX - 1-ia polovina XX veka, Moskva: IVI RAN, pp. 234- 235.

Gusachenko, A. (2019), 'The social activity of the Russian youth movements in the Republic of Latvia (1920-1940), in Dialogue with Time, no. 68, Moscow: Russian Academy of Sciences, pp. 60-67.

Gusačenko, A. (2019), 'Latvijas Neatkarības karš krievu iedzīvotāju skatījumā 1919. gada pirmajā pusē' [Latvian War of Independence from the perspective of the Russian population in the first half of 1919], Latvijas Vēstures institūta žurnāls [Journal of the Institute of Latvian History], vol. 1, pp. 49-52.

https://doi.org/10.22364/lviz.109.03

Jēkabsons, Ē. (1996), Poḷi Latvijā [Polish in Latvia], Rīga: LU, FSI.

Jēkabsons, Ē. (2001), 'Baltkrievi Latvijā 1918.-1940. gadā' [Belarusians in Latvia in 1918-1940], Latvijas Vēstures Institūta Žurnāls [Journal of the Institute of Latvian History], vol. 4. 
Jēkabsons, Ē. (2003), Lietuvieši Latvijā [Lithuanians in Latvia], Rīga: Elpa.

Jēkabsons, Ē. (2013), Aizmirstie karavīri-ebreji Latvijas armijā 1918.-1940. gadā [The forgotten soldiers: Jews in the Latvian army in 1918-1940], Rīga: Šamir.

Jēkabsons, $\overline{\mathbf{E}}$. (2018), Latvijas un Amerikas Savienoto Valsts attiecības 1918.-1922. gad̄̄ [Relations of Latvia and the USA, 1918-1922], Rìga: LU, LVI. https://doi.org/10.22364/lviz.108.08

Jundzis, T. (2013), 'Latvijas neatkarības atjaunošanas dažādie ceḷi: tiesiskais pamatojums un īstenošana (1989-1991)' [The different ways of restoring Latvia's independence: legal basis and implementation (1989-1991)], Latvijas Zinātñu Akadèmijas Vēstis [Proceedings of the Latvian Academy of Sciences], vol. 67 , no. $1 / 2$, pp. $4-22$.

Jundzis, T. (2014), 'Krievijas karaspēka izvešana no Latvijas 1992-1994: diplomātiska uzvara vai politiska piekāpšanās?' [Withdrawal of Russian troops from Latvia in 1992-1994: a diplomatic victory or political concession?] Latvijas Zinātñu Akadèmijas Vēstis [Proceedings of the Latvian Academy of Sciences], vol. 68 , no. $3 / 4$, pp. $4-23$.

Klišāns, V. (2018), Latvijas vēsture. No vissenākajiem laikiem līdz mūsdienām Baltijas, Eiropas un pasaules vēstures kontekstā [Latvian history. From the earliest times to the present day in the context of the Baltic, European and world history], Rīga: Zvaigzne ABC.

Krūminsš, G. (2018), 'Neatkarības atjaunošana' [Restoration of independence], in V. Ščerbinskis (ed.) Nacionālā enciklopēdija. Latvija [National Encyclopedia. Latvia], Rīga: Latvijas Nacionālā bibliotēka, pp. 133-137.

Latvija Parīzes miera konferencē 1919. gad̄̄ (2017), [Latvia at the Paris Peace Conference in 1919], Vēstures avoti IX [Historical sources, 9], Rīga: Latvijas Nacionālais arhīvs.

Law on the Statehood of the Republic of Latvia (1991), Supreme Council of the Republic of Latvia, 21.8.1991. Retrieved from https://ikumi.lv/ta/en/id/69512law-on-the-statehood-of-the-republic-of-latvia [accessed 23 Aug 2019]

Lerhis, A. (2005), Latvijas Republikas ārlietu dienests [Foreign services of the Republic of Latvia], Rīga: LR Ārlietu ministrija.

Ministry of Foreign Affairs of the Republic of Latvia (2019), Recognition of Latvia's Independence de jure. Retrieved from https://www.mfa.gov.lv/en/news/latestnews/latest-infographics/55914-recognition-of-latvia-s-independence [accessed 17 Sep 2019]

Naturalization Board of the Republic of Latvia (2009), 2009.gada darba pārskats [Annual Report of 2009], Riga. Retrieved from https://www.pmlp.gov.lv/lv/ sakums/jaunumi/publikacijas/gada-parskati/naturalizacijas-parvaldes-2009. gada-parskats-(pdf).pdf [accessed 12 Aug 2019] 
Par Latvijas Republikas neatkarības atjaunošanu (1990), [Law on the Restoration of Independence of the Republic of Latvia], Latvijas Padomju Sociālistiskās Republikas Augstākās Padomes deklarācija [Declaration of the Supreme Council of the Soviet Socialist Republic of Latvia], 4.5.1990. Retrieved from https://likumi.lv/doc.php?id=75539 [accessed 2 Aug 2019]

Par Latvijas Republikas pilsoņu tiesību atjaunošanu un naturalizācijas pamatnoteikumiem (1991), [Law on the Restoration of the Rights of Citizens of the Republic of Latvia and the Basic Rules of Naturalization], Latvijas Republikas Augstākās Padomes lēmums [Decision of the Supreme Council of the Republic of Latvia], 15.10.1991. Retrieved from https://m.likumi.lv/doc. php?id=69914 [accessed 19 Aug 2019]

Pilsonības likums (1994), [Law on Citizenship], Latvijas Republikas Saeima [Saeima of the Republic of Latvia], 11.8.1994. Retrieved from https://www.vestnesis.lv/ ta/id/57512 [accessed 6 Sep 2019]

Počs, K. (1971), “Sanitāra kordona” valgos [In the Snare of Sanitary Cordon], Rīga: Zinātne.

Sarkanis, A. (1999), Dokumenti par Latvijas valsts starptautisko atzīšanu, neatkarības atjaunošanu un diplomātiskiem sakariem. 1918.-1998. [Documents on the international recognition of the State of Latvia, restoration of independence and diplomatic relations. 1918-1998], Rīga: Nordik.

Seskis, J. (1938), Latvijas valsts izcelšanās pasaules kara notikumu norisē [The beginnings of the state of Latvia in the course of events of the world war], Riga: Valters un Rapa.

Skujenieks, M., ed. (1925), Otrā tautas skaitīšana, M. Skujenieka redakcijā [The Second Census, ed. by M. Skujenieks], Rīga: Latvijas statistikas pārvalde.

Spārīts, O. \& Dribins, L. (2000), Vācieši Latvijā [Germans in Latvia], Rīga: LU, FSI.

Stranga, A. (2010), Ebreji un latvieši neatkarīgās Latvijas izcīnīšanas laikā: 1918.-1920. [Jews and Latvians during the conquest of independent Latvia: 1918-1920]. Retrieved from https://www.lu.lv/jsc/pilsetas/kultura-untradicijas/1918-1920/ [accessed 21 Sep 2019]

Šilde, A. (1976), Latvijas vēsture 1914-1940. Valsts tapšana un suverenā valsts [History of Latvia 1914-1940. Formation of the state and sovereign state], Stockholm: Daugava.

Šilde, A. (2007), Valstsvīri un demokrāti [Statesmen and democrats], Rīga: Eraksti. Šiliņš, J. (2019), 'Padomju Krievija lūdz pamieru Latvijai - iespēja mieram vai viltība?' [Soviet Russia is asking for a truce in Latvia - a trick or an opportunity for peace?] $L S M, 11.9 .2019$. Retrieved from https://www.lsm.lv/raksts/dzive-stils/vesture/padomju-krievija-ludz-pamieru-latvijai-iespeja-mieram-vaiviltiba.a331594/ [accessed 17 Sep 2019] 
Andrejs Gusachenko

Vineta Kleinberga

Wood, A. (1997), Critical Companion to the Russian Revolution, 1914-1921, Bloomington, IN: Indiana University Press.

Zvidriņš, P. (2018) 'Iedzīvotāju etniskais sastāvs' [Ethnic composition of the population] in V. Ščerbinskis (ed.) Nacionālā enciklopēdija. Latvija [National Encyclopedia. Latvia], Rīga: Latvijas Nacionālā bibliotēka, pp. 503-507.

https://doi.org/10.22364/talsai.08 